\title{
Keefektifan Model Pembelajaran Problem Posing Terhadap Pemecahan Masalah Matematika
}

\author{
Sheila Rosa Firdayanti ${ }^{1}$, Filia Prima Artharina ${ }^{2}$, Veryliana Purnamasari ${ }^{3}$ \\ ${ }^{123}$ Jurusan Pendidikan Guru Sekolah Dasar \\ Universitas PGRI Semarang \\ Semarang, Indonesia \\ e-mail: shelarosalina@gmail.com
}

\begin{abstract}
Abstrak
Penelitian ini bertujuan untuk mengetahui perbedaan peningkatan kemampuan pemecahan masalah matematika sebelum dan sesudah diberi perlakuan menggunakan model pembelajaran Problem Posing. Penelitian ini menggunakan Pre Experimental Design bentuk One Group Pretest Posttest Design. Subyek penelitian melibatkan seluruh siswa kelas V SD Negeri Pleburan 01 Semarang. Instrumen penelitian berupa pedoman observasi, tes dan dokumentasi. Uji coba instrumen menggunakan uji validitas, reliabilitas, daya pembeda dan taraf kesukaran. Pengujian statistik menggunakan uji normalitas awal dan akhir, uji hipotesis (ttest) dan uji ketuntasan individu maupun klasikal. Hasil penelitian menunjukkan bahwa kemampuan pemecahan masalah matematika mengalami peningkatan setelah diberi perlakuan menggunakan model pembelajaran Problem Posing.
\end{abstract}

Kata kunci: model pembelajaran problem posing, pemecahan masalah matematika

\begin{abstract}
This study aims to determine the differences in increasing mathematical problem solving abilities before and after being treated using Problem Posing learning models. This study uses Pre Experimental Design in the form of One Group Pretest Posttest Design. The research subjects involved all fifth grade students of Pleburan 01 Elementary School Semarang. The research instrument was in the form of observation, test and documentation guidelines. Instrument testing uses validity, reliability, differentiation and difficulty levels. Statistical testing uses the initial and final normality test, hypothesis testing (t-test) and individual and classical completeness tests. The results of the study showed that mathematical problem solving abilities had increased after being treated using Problem Posing learning models
\end{abstract}

Keywords: Problem Posing learning model, mathematical problem solving 


\section{Pendahuluan}

Formal Pemecahan masalah terdiri dari serangkaian aktivitas pembelajaran yang menekankan penyelesaian masalah yang dihadapi secara ilmiah. Dalam memperoleh kemampuan pemecahan masalah, seseorang harus memiliki banyak pengalaman dalam memecahkan berbagai masalah. Untuk itu, kemampuan pemecahan yang telah dimiliki oleh seorang individu bisa menjadi bekal dirinya dalam mengahadapi segala sesuatu dan akan mudah dalam menyelesaikan setiap masalah yang dihadapi.

Menurut Noer (2017:69) secara metodologis, pemecahan masalah bisa sebagai pendekatan, bisa sebagai strategi atau metode pemecahan masalah. Sebagai metode belajar, merupakan cara atau perlakuan terhadap materi (masalah) sehingga terbangun interaksi siswa dengan masalah yang dipecahkan hingga diperoleh pemecahan. Selain itu, pemecahan masalah dapat dipandang sebagai aturan-aturan yang dapat diterapkan dalam upaya untuk mengatasi situasi yang baru. Jadi, pemecahan masalah tidak hanya sekedar bentuk kemampuan dalam menerapkan aturan yang telah individu kuasai melalui kegiatan belajar terlebih dahulu melainkan dapat menggunakan cara baru untuk mengatasi masalah di situasi yang baru.Konsep metode belajar atau pembelajaran pemecahan masalah membutuhkan caracara spesifik agar pemecahan masalah sebagai proses dan keterampilan dasar dapat diikuti dan dilakukan siswa hingga mencapai tujuan pemecahan masalah. Secara aktual, kemampuan pemecahan masalah ditempuh dengan menerapkan strategi dan pendekatan pemecahan masalah. Pendekatan pemecahan masalah berarti guru menyajikan pemecahan masalah sebagai proses yang dilakukan dengan tahapan tertentu yang menurut para ahli dengan tahapan pokok.

Merencanakan pembelajaran pemecahan masalah bagi siswa harus sesuai dengan indikator-indikator pemecahan masalahnya agar permasalahan dapat terselesaikan dengan baik. Adapun indikator pemecahan masalahnya menurut Sumarmo (2013:5) yaitu: 1) Mengidentifikasi unsur-unsur yang diketahui, yang ditanyakan, dan kecukupan unsur yang diperlukan, 2) Merumuskan masalah matematik atau menyusun model matematika, 3) Menerapkan strategi untuk menyelesaikan berbagai masalah (sejenis dan masalah baru) dalam atau di luar matematika, 4) Menjelaskan atau menginterpretasikan hasil sesuai permasalahan asal, 5) Menggunakan matematika secara bermakna.

Berdasarkan indikator tersebut, guru dapat mengukur sejauh mana siswa dapat menyelesaikan pemecahan masalah ketika berlngasungnya pembelajaran didalam kelas.

Noer (2017:71) menyatakan bahwa pemecahan masalah sebagai materi pelajaran, tujuan pelajaran, proses belajar, dan keterampilan dasar, diajarkan bagi peserta didik dengan berprinsip pada beberapa konsep, yaitu:

1. Pengajaran diawali dengan analisis tujuan yang relevan dengan tujuan pemecahan masalah.

2. Pengajaran dengan menyiapkan dan memanfaatkan pemahaman, keterampilan, dan pengetahuan prasyarat sesuai konteks masalah yang dipecahkan.

3. Inti pembelajaran pemecahan masalah adalah melakukan aktivitas pemecahan masalah yang tidak biasa dan bermakna bagi siswa, menggunakan pendekatan pemecahan masalah dari Polya.

4. Menggunakan pendekatan pedagogis dan personal untuk mendorong dan menarik siswa senang melaksanakan tugas pemecahan masalah.

5. Memberikan dan melatih penggunaan berbagai strategi untuk memecahkan masalah yang bervariasi.

6. Menggunakan metode penemuan dan variasi metode lainnya dengan bantuan atau tuntunan yang relevan dengan kebutuhan pengembangan strategi pemecahan masalah yang diberikan.

7. Melakukan penilaian kemampuan pemecahan masalah yang sesuai dengan tujuan pembelajaran.

Berdasarkan beberapa prinsip di atas, kemampuan pemecahan masalah harus dimiliki siswa untuk melatih agar terbiasa menghadapi berbagai permasalahan, baik masalah dalam matematika, masalah dalam bidang studi lain ataupun masalah dalam kehidupan sehari-hari yang semakin kompleks melalui cara penyelesaian dengan langkah-langkah tertentu menurut Hadi (2014:54), yaitu: 
a) Memahami masalah

Tahap pertama pada penyelesaian masalah adalah memahami soal. Siswa perlu mengidentifikasi apa yang diketahui, apa saja yang ada, jumlah, hubungan dan nilai-nilai yang terkait serta apa yang sedang mereka cari. Tanpa adanya pemahaman terhadap masalah yang diberikan, siswa tidak mungkin mampu menyelesaikan masalah tersebut dengan benar.

b) Merencanakan penyelesaian

Pada tahap ini, siswa perlu mengidentifikasi operasi yang terlibat serta strategi yang diperlukan untuk menyelesaikan masalah yang diberikan. Kemampuan menyelesaikan ini sangat tergantung pada pengalaman siswa. Jadi, semakin bervariasi pengalaman siswa ada kecenderungan siswa lebih kreatif dalam merencanakan penyelesaian masalah.

c) Menyelesaikan masalah sesuai dengan rencana

Siswa perlu mempertahankan rencana penyelesaian yang sudah dipilih pada tahap menyelesaikan masalah. Jika rencana tidak sesuai dengan yang dipilih, maka siswa dapat menggunakan cara yang lain.

d) Melakukan pengecekan kembali

Langkah keempat yaitu melakukan pengecekan terhadap apa yang telah dilaksanakan mulai dari langkah pertama sampai langkah ketiga dan ditarik sebuah kesimpulan.

Kemampuan pemecahan masalah harus dimiliki siswa untuk melatih agar terbiasa menghadapi berbagai permasalahan, baik masalah dalam matematika, masalah dalam bidang studi lain ataupun masalah dalam kehidupan sehari-hari yang semakin kompleks. Oleh sebab itu kemampuan siswa untuk memecahkan masalah matematika perlu terus dilatih sehingga ia dapat memecahkan masalah yang mereka hadapi. Namun, fakta di lapangan belumlah sesuai dengan apa yang diharapkan. Berdasarkan observasi yang telah di laksanakan di SD Negeri Pleburan 01 Semarang, ditemukan fakta bahwa ada beberapa siswa yang belum bisa mengikuti pembelajaran matematika terkait dengan soal pemecahan masalah sehingga siswa kesulitan menangkap beberapa materi dari guru dan ada pula siswa yang ramai sendiri ketika guru sedang menjelaskan materi pembelajaran. Menurut beliau, siswa kelas $\mathrm{V}$ memiliki rasa keingintahuan yang cukup tinggi mengenai soal pemecahan masalah, tetapi untuk memecahkan soal cerita matematika yang diberikan kembali pada kemampuan siswanya masing-masing. Beberapa masalah yang timbul ketika berlangsungnya pembelajaran karena beliau belum menerapkan model dan tidak menggunakan media pembelajaran karena keterbatasan sarana dan prasarana dari sekolah. Padahal penggunaan model ataupun media dalam kegiatan pembelajaran mampu memusatkan perhatian siswa. Dengan penerapan model pembelajaran yang sesuai dan menarik, siswa dapat secara maksimal menyerap materi yang dijelaskan oleh guru.

Berdasarkan permasalahan tersebut, peneliti memilih model pembelajaran yang sesuai yaitu model pembelajaran Problem Posing. Model Problem Posing dipilih dengan alasan dapat mendidik murid berpikir kritis, siswa menjadi aktif dalam pembelajaran, siswa dapat belajar manganalisis suatu masalah dan mendidik anak percaya pada diri sendiri. Pembelajaran dengan menerapkan model pembelajaran problem posing, pada prinsipnya siswalah yang harus aktif mengembangkan pengetahuan mereka, bukan guru atau orang lain. Penekanan belajar siswa aktif ini dalam dunia pendidikan terlebih di Indonesia kiranya sangat penting dan perlu. Kreativitas dan keaktifan siswa akan membantu mereka untuk berdiri sendiri dalam kehidupan kognitif mereka. Adapun langkah-langkah dalam model pembelajaran problem posing menurut Thobroni (2017:287) yaitu: 1) Guru menyampaikan tujuan pembelajaran dan memotivasi siswa untuk belajar, 2) Guru menyampaikan informasi baik secara lewat bahan bacaan selanjutnya memberi contoh cara membuat soal dari informasi yang diberikan, 3) Guru membentuk kelompok belajar antara 4-6 peserta didik tiap kelompok. Guru pun dapat meminta siswa untuk berpasangan 2 orang, 4) Guru meminta siswa untuk membuat soal, 5) Selama kerja kelompok berlangsung guru membimbing kelompok-kelompok yang mengalami kesulitan dalam membuat soal dan menyelesaikannya, 6) Guru mengevaluasi hasil belajar tentang materi yang dipelajari dengan cara masing-masing kelompok mempresentasikan hasil pekerjaannya.

Berdasarkan uraian tersebut maka dalam penelitian ini peneliti memilih judul "Keefektifan Model Pembelajaran Problem Posing Terhadap Pemecahan Masalah Matematika Kelas V SD Negeri Pleburan 01 Semarang". 
TSCJ, Vol 2 No 2, Tahun 2019

p-ISSN : 2615-4692 e-ISSN : 2615-6105

\section{Metode}

Penelitian ini menggunakan Pre Experimental Design bentuk One Group Pretest Posttest Design. Desain ini digambarkan sebagai berikut:

Tabel 1. .Rancangan Penelitian

\begin{tabular}{ccc}
\hline Pretest & Perlakuan & Posttest \\
\hline $\mathrm{O}_{1}$ & $\mathrm{X}$ & $\mathrm{O}_{2}$ \\
\hline & & Sugiyono (2015:74)
\end{tabular}

Keterangan:

$\begin{array}{ll}\mathrm{O}_{1} & =\text { Pretest setelah diberikan model pembelajaran problem posing } \\ \mathrm{O}_{2} & =\text { Posttest setelah diberikan model pembelajaran problem posing } \\ \mathrm{X} & =\text { Perlakuan model pembelajaran problem posing }\end{array}$

Variabel penelitian yang digunakan ada dua yaitu variabel independen (bebas) dan variabel dependen (terikat). Yang menjadi variabel bebas adalah model pembelajaran Problem Posing sedangkan kemampuan pemecahan masalah matematika materi volume kubus dan balok siswa kelas V SD Negeri Pleburan 01 Semarang.

\section{Hasil dan Pembahasan}

Penerapan model Problem Posing menunjukkan adanya peningkatan hasil belajar matematika mengenai pemecahan masalah berdasarkan perhitungan analisis data awal dan analisis data akhir. Selain meningkatkan hasil belajar, kemampuan memecahkan masalah siswa pada pembelajaran matematika ikut meningkat seperti yang terlihat pada tabel berikut ini

Tabel 2 . Persentase Peningkatan Kemampuan Pemecahan Masalah Berdasarkan Indikator

\begin{tabular}{|c|c|c|c|c|}
\hline \multirow{2}{*}{ No. } & \multirow{2}{*}{ Indikator } & \multicolumn{3}{|c|}{ Pertemuan ke- } \\
\hline & & 1 & 2 & 3 \\
\hline 1 & $\begin{array}{l}\text { Mengidentifikasi unsur-unsur yang diketahui, yang } \\
\text { ditanyakan dan kecukupan unsur yang diperlukan. }\end{array}$ & $8 \%$ & $12 \%$ & $16 \%$ \\
\hline 2 & $\begin{array}{l}\text { Merumuskan masalah matematik atau menyusun model } \\
\text { matematika. }\end{array}$ & $12 \%$ & $16 \%$ & $20 \%$ \\
\hline 3 & $\begin{array}{l}\text { Menerapkan strategi untuk menyelesaikan berbagai } \\
\text { masalah (sejenis dan masalah baru) dalam atau diluar } \\
\text { matematika. }\end{array}$ & $12 \%$ & $16 \%$ & $20 \%$ \\
\hline 4 & $\begin{array}{l}\text { Menjelaskan atau menginterpretasikan hasil sesuai } \\
\text { permasalahan asal. }\end{array}$ & $8 \%$ & $16 \%$ & $20 \%$ \\
\hline 5 & Menggunakan matematika secara bermakna. & $8 \%$ & $16 \%$ & $20 \%$ \\
\hline
\end{tabular}

Berdasarkan tabel diatas, observasi dilaksanakan selama 3 pertemuan. Hasil observasi dapat dilihat bahwa pada pertemuan pertama dengan indikator mengidentifikasi unsur-unsur yang diketahui, yang ditanyakan dan kecukupan unsur yang diperlukan diperoleh persentase hasil $8 \%$. Hal ini disebabkan karena siswa belum terbiasa untuk menghadapi soal pemecahan masalah matematika dalam kegiatan pembelajaran. Jadi, mereka belum bisa membedakan manakah unsur yang tergolong diketahui, ditanyakan dan dijawab. Mereka masih kebingungan untuk mengidentifikasinya karena pada dasarnya mereka memang belum memahami soal pemecahan masalah tersebut. Pada observasi pertemuan ketiga terjadi peningkatan dari $8 \%$ menjadi $16 \%$. Hal ini disebabkan karena pada pertemuan ketiga siswa telah dijelaskan dan diberikan contoh soal pemecahan masalah. Siswa dituntun untuk mengidentifikasi unsur-unsur yang ada dalam soal supaya mereka terbiasa dan memahami maksud dari soal tersebut.

Observasi pertama pada indikator kedua yaitu merumuskan masalah matematik atau menyusun model matematika dengan persentase hasil yang diperoleh sebesar $12 \%$. Hal ini disebabkan karena siswa belum memahami sepenuhnya maksud dari soal pemecahan masalah yang diberikan, jadi mereka masih kebingungan untuk merumuskan model matematikanya. Hasil 
observasi selanjutnya pada pertemuan ketiga diperoleh peningkatan hasil sebesar $20 \%$ karena pada pembelajaran pertemuan ketiga ini siswa telah diajarkan bagaimana cara menyusun model matematika tentunya dengan menerapkan model pembelajaran Problem Posing dalam pembelajaran tersebut.

Observasi pertemuan pertama pada indikator ketiga yaitu menerapkan strategi untuk menyelesaikan berbagai masalah (sejenis dan masalah baru) dalam atau diluar matematika diperoleh persentase hasil sebesar $12 \%$. Hal ini disebabkan karena siswa masih kebingungan untuk merumuskan masalah yang terlihat pada indikator kedua. Mereka kebingungan dengan maksud dari soal pemecahan yang diberikan jadi mereka belum bisa memilih strategi yang cocok untuk memecahkan soal tersebut. Pada pertemuan ketiga terjadi peningkatan yang signifikan dari $12 \%$ menjadi $20 \%$ yang artinya dengan diterapkannya model Problem Posing dalam pembelajaran siswa sudah terlatih untuk menentukan strategi apa yang cocok untuk memecahkan soal tersebut dengan cara berdiskusi dengan teman kelompok atau pasangannya.

Observasi pertemuan pertama pada indikator keempat yaitu menjelaskan atau menginterpretasikan hasil sesuai permasalahan asal diperoleh persentase hasil sebesar $8 \%$ yang tergolong cukup rendah. Hal ini disebabkan siswa belum bisa mempresentasikan hasil dengan baik karena dalam pembelajaran sebelumnya siswa hanya mendengarkan penjelasan dari guru tanpa mengungkapkan pendapatnya. Pertemuan ketiga terjadi peningkatan dari $8 \%$ menjadi $20 \%$. Peningkatan ini disebabkan telah diterapkannya model Problem Posing yang mengajak siswa untuk berdiskusi dan mengungkapkan pendapatnya masing-masing. Hal ini melatih pola pikir siswa dan melatih keberanian siswa untuk mengungkapkan pendapatnya didepan teman-temannya.

Observasi pada indikator kelima yaitu menggunakan matematika secara bermakna diperoleh persentase hasil sebesar $8 \%$. Hal ini disebabkan karena masih rendahnya persentase dari indikator pertama sampai dengan keempat sehingga pada indikator kelima siswa belum bisa mencapai hasil yang maksimal. Pada pertemuan ketiga terjadi peningkatan dari persentase hasil $8 \%$ menjadi $20 \%$ karena telah diterapkannya model Problem Posing dalam pembelajaran sehingga terjadi peningkatan yang signifikan dari indikator pertama sampai dengan kelima.

Berdasarkan tabel tersebut, untuk lebih jelasnya dapat dilihat pada grafik dibawah ini

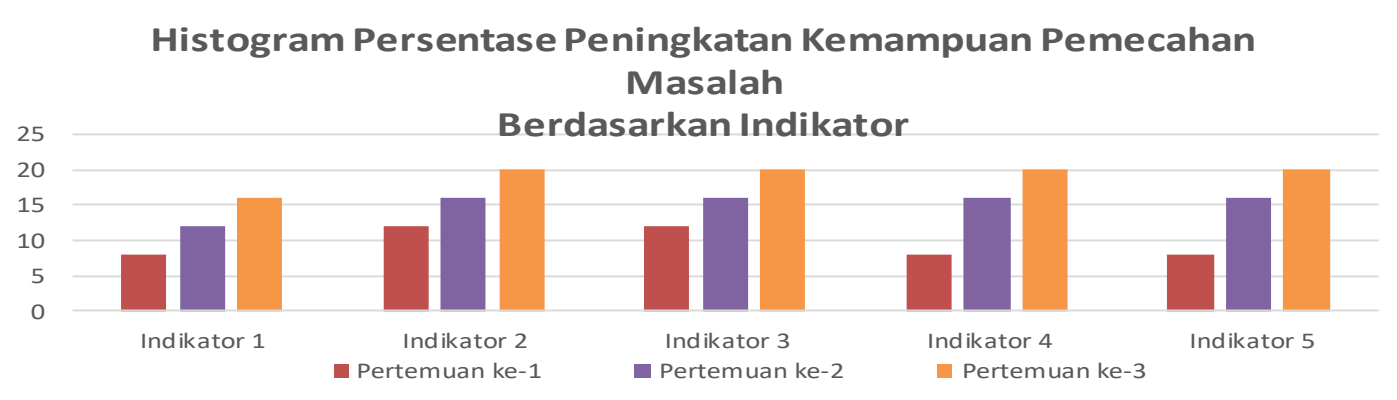

Keterangan:

1. Mengidentifikasi unsur-unsur yang diketahui, yang ditanyakan dan kecukupan unsur yang diperlukan.

2. Merumuskan masalah matematik atau menyusun model matematika.

3. Menerapkan strategi untuk menyelesaikan berbagai masalah (sejenis dan masalah baru)

4. Menjelaskan atau menginterpretasikan hasil sesuai permasalahan asal.

5. Menggunakan matematika secara bermakna.

\section{Gambar 2. Histogram Persentase Peningkatan Kemampuan Pemecahan Masalah Berdasarkan Indikator}

Dari data diatas, peneliti dapat menyimpulkan bahwa model pembelajaran Problem Posing memiliki pengaruh yang kuat terhadap kemampuan pemecahan masalah matematika siswa kelas V SD Negeri Pleburan 01 Semarang 
TSCJ, Vol 2 No 2, Tahun 2019

\section{Simpulan Dan Saran}

Berdasarkan pada hasil analisis data dalam penelitian ini dapat disimpulkan bahwa kemampuan pemecahan masalah matematika setelah diberi perlakuan menggunakan model pembelajaran Problem Posing meningkat daripada sebelum diberikan perlakuan menggunakan model pembelajarn Problem Posing. Peningkatan tersebut dapat dilihat dari persentase hasil yang diperoleh dari observasi kemampuan pemecahan masalah berdasarkan indikator yang telah ada.

Berdasarkan simpulan dari hasil penelitian tersebut disarankan kepada guru SD Negeri Pleburan 01 Semarang khususnya dan guru-guru di sekolah yang lain dalam mengajar matematika hendaknya menggunakan model Problem Posing (pengajuan masalah). Bagi pembuat kebijakan dalarn bidang pendidikan matematika di tingkat Kota maupun provinsi hendaknya memberikan sosialisasi bagi guru-guru sekolah dasar yang mengajar matematika tentang model problem posing dalam pembelajaran matematika. Bagi para peneliti lanjutan, dapat mengembangkan penelitian serupa dengan pokok bahasan dan populasi yang berbeda

\section{Daftar Pustaka}

Noer, Sri Hastuti. 2017. Strategi Pembelajaran Matematika. Yogyakarta: Matematika.

Hadi, Soetarto, Radiyatul. 2014. "Metode Pemecahan Masalah Menurut Polya Untuk Mengembangkan Kemampuan Siswa Dalam Pemecahan Masalah Matematis Di Sekolah Menengah Pertama". Jurnal Pendidikan Matematika, 2 (1), 53-61.

Thobroni, M. 2017. Belajar dan Pembelajaran. Yogyakarta: Ar-Ruzz Media.

Sugiyono. 2015. Metode Penelitian Pendidikan. Bandung: Alfabeta 